\title{
The effect of a high forage diet and different oil blends on rumen fermentation in vitro*
}

\author{
D. Jaľ̌ , A. Potkański², M. Szumacher-Strabel ${ }^{2}$, J. Kowalczyk ${ }^{3}$ \\ and A. Cieślak ${ }^{2}$ \\ ${ }^{1}$ Institute of Animal Physiology, Slovak Academy of Sciences \\ Soltesovej 4-6, 04001 Košice, Slovak Republic \\ ${ }^{2}$ The August Cieszkowski Agricultural University of Poznań, \\ Department of Animal Nutrition and Feed Management \\ Wotyńska 33, 60-637 Poznań, Poland \\ ${ }^{3}$ The Kielanowski Institute of Animal Physiology and Nutrition, Polish Academy of Sciences \\ 05-110 Jabtonna, Poland
}

\begin{abstract}
The experiment was carried out in a Rusitec system. The effect of diet (control-fresh lucerne plus maize, 60:40\%) and fat sources (linseed LO, rapeseed RO, fish FO oils) as oil blends (LO+RO, FO+LO, $\left.\mathrm{FO}+\mathrm{LO}+\mathrm{RO}, 5 \% \mathrm{wt}_{\mathrm{wt}} \mathrm{wt}^{-1}\right)$ on rumen fermentation was studied. The experiment lasted 13 days. To ensure a steady state within the Rusitec vessels a 7-day adaptation period preceded a 6-day collection period. The diet with a $5 \%$ addition of oil blends, $\mathrm{LO}+\mathrm{RO}, \mathrm{LO}+\mathrm{FO}, \mathrm{LO}+\mathrm{FO}+\mathrm{RO}$, was added to the fermentation vessels daily. Supplementation with blends (LO+RO, LO+FO, LO+FO+RO) did not affect some basal parameters of rumen fermentation ( $\mathrm{pH}$, total VFA production, dry matter digestibility) in comparison with the control. Detergent fibre digestibility was significantly reduced, mainly with LO+RO+FO (NDF, ADF, cellulose) and LO+RO (ADF). The oil blends significantly reduced the mol\% of acetate, n-butyrate, $\mathrm{A} / \mathrm{P}$ ratio, and increased the mol $\%$ of propionate. The oil blends supplemented to the high forage diet significantly $(\mathrm{P}<0.005)$ decreased the efficiency of microbial protein synthesis.
\end{abstract}

KEY WORDS: artificial rumen, lucerne, maize, oil blends, rumen fermentation

\section{INTRODUCTION}

Diets for ruminants should usually be improved in energy using oils as fat supplements. Commercial quantities of oils are obtained from animals, plants, algae, yeasts, filamentous fungi, and bacteria, although vegetable oils are the major sources. Recent

\footnotetext{
* Supported by the Grant Agency of the Slovak Academy of Sciences, Grant No. 2/6174/6 and the State Committee for Scientific Research (Poland), Grant No. 3 P06Z 05923

${ }^{1}$ Corresponding author: e-mail: jalcd@saske.sk
} 
results of many numerous studies support the hypothesis that oils should be supplemented to the ration of ruminants as blends (AbuGhazaleh et al., 2004). In this study, the effect of a high forage diet (fresh lucerne plus maize 60:40\%) and its supplementation with fat (rapeseed oil RO, linseed oil LO, fish oil FO as blends: $\mathrm{RO}+\mathrm{LO}, \mathrm{FO}+\mathrm{LO}$, $\mathrm{RO}+\mathrm{LO}+\mathrm{FO}$ ) on rumen fermentation in an artificial rumen was studied.

\section{MATERIAL AND METHODS}

\section{Animals and diets}

The rumen simulation technique and rumen fluid supply of Rusitec equipment and chemical composition of feed was described by Jalč et al. (2006a).

The animals were fed with fresh lucerne ( $960 \mathrm{~g}$ of DM) and crushed maize (240 $\mathrm{g}$ of DM) daily. In the Rusitec, all of the fermentation vessels were supplied with $18 \mathrm{~g}(5.4 \mathrm{~g} \mathrm{DM})$ of fresh lucerne and $4.13 \mathrm{~g}(3.6 \mathrm{~g} \mathrm{DM})$ of crushed maize together with the addition of oil blends, $5 \% \mathrm{wt}^{\cdot} \cdot \mathrm{wt}^{-1}: \mathrm{LO}+\mathrm{RO}, \mathrm{LO}+\mathrm{FO}$, and $\mathrm{LO}+\mathrm{FO}+\mathrm{RO}$.

\section{Measurements and chemical analyses}

To ensure a steady state within the vessels, a 7-day adaptation period preceded a 6-day collection period. On days 8-13, the samples were collected and analysed for volatile fatty acids (VFA), nitrogen, and ammonia nitrogen $\left(\mathrm{NH}_{3}-\mathrm{N}\right)$ in effluent; dry matter, NDF and ADF, ash and nitrogen in feed and refusals, respectively. Other fermentation variables, i.e. fermentation efficiency (E), organic matter fermented (OMF), nitrogen incorporated by microflora $\left(\mathrm{N}_{\mathrm{M}}\right)$, efficiency of microbial protein synthesis (EMS), were calculated according to the stoichiometry of rumen fermentation. These procedures were described in a previous study (Jalč and Čertík, 2005).

\section{Statistical analysis}

Means of results from treatments were compared with one-way analysis of variance (ANOVA). Treatment means were statistically compared by the TukeyKramer multiple comparison test. The tables give the group means and the standard error of the mean.

\section{RESULTS AND DISCUSSION}

The fermentation of the diets was carried out at $\mathrm{pH}$ 6.88-6.95 (Table 1).The results showed that the $\mathrm{NH}_{3}-\mathrm{N}$ concentration was significantly higher in vessels 
supplemented with oil blends. The rumen degradation of dry matter (DMD) after $48 \mathrm{~h}$ of incubation in fermentation fluid was slightly $(\mathrm{P}<0.05)$ reduced with the oil blends supplemented to the high forage diet. Also the apparent digestibility of dry matter and organic matter did not differ significantly when sheep were fed fat $\left(60 \mathrm{~g} \cdot \mathrm{kg}^{-1}\right.$ fatty acids) from different sources, i.e. linseed, fish oil, linfish (linseed+fish oil; Wachira et al., 2000). In our experiment, the oil blends LO+RO and LO+FO slightly (NS) reduced, and LO+FO+RO significantly reduced, NDF and ADF digestibility (about 7 and 9 percentage units) in the diet. Cellulose and hemicellulose digestibilities were slightly decreased (about 1-4 percentage units) with $\mathrm{LO}+\mathrm{RO}, \mathrm{LO}+\mathrm{RO}+\mathrm{FO}$ blends and slightly increased with $\mathrm{LO}+\mathrm{FO}$ blends (about 2-3 percentage units). The oil blend (LO+RO) significantly, and the other oil blends (FO+LO, FO+LO+RO) slightly, reduced acetate production in the high forage diet. The molar proportions of acetate were, however, significantly reduced with all oil blends (Table 1). Supplementation with the LO+FO blend significantly

Table 1. Effect of the diet consisting of fresh lucerne and maize (60:40\%) supplemented with oil blends on the rumen fermentation pattern in a Rusitec $(n=6)$

\begin{tabular}{|c|c|c|c|c|}
\hline \multirow{2}{*}{ Item } & \multicolumn{4}{|c|}{ The type of added oil blend $\left(5 \% \mathrm{wt} \cdot \mathrm{wt}^{-1}\right)$} \\
\hline & control $^{\mathrm{a}}$ & $\mathrm{LO}+\mathrm{RO}^{\mathrm{b}}$ & $\mathrm{FO}+\mathrm{LO}^{\mathrm{c}}$ & $\mathrm{FO}+\mathrm{LO}+\mathrm{RO}^{\mathrm{d}}$ \\
\hline $\mathrm{pH}$ & $6.88 \pm 0.05$ & $6.91 \pm 0.04$ & $6.95 \pm 0.06$ & $6.94 \pm 0.04$ \\
\hline $\mathrm{DMD}, \%$ & $78.91 \pm 2.12$ & $72.17 \pm 2.21$ & $77.20 \pm 2.14$ & $76.65 \pm 2.41$ \\
\hline NDF, $\%$ & $82.02 \pm 2.32^{\mathrm{d}}$ & $75.85 \pm 2.35$ & $80.58 \pm 2.12$ & $75.08 \pm 2.26$ \\
\hline $\mathrm{ADF}, \%$ & $82.59 \pm 2.31^{\mathrm{b}}$ & $75.17 \pm 2.14$ & $78.54 \pm 2.36$ & $73.15 \pm 2.45^{\mathrm{a}}$ \\
\hline Hemicellulose, \% & $81.47 \pm 2.48$ & $76.82 \pm 2.36^{\mathrm{c}, \mathrm{d}}$ & $83.25 \pm 2.52$ & $83.25 \pm 2.41$ \\
\hline Cellulose, $\%$ & $85.55 \pm 2.32$ & $84.26 \pm 2.38$ & $88.04 \pm 2.42^{\mathrm{d}}$ & $82.51 \pm 2.35^{\mathrm{a}}$ \\
\hline $\mathrm{NH}_{3}-\mathrm{N}, \mathrm{mg} .100 \mathrm{ml}$ & $19.35 \pm 2.41^{\mathrm{b}, \mathrm{c}, \mathrm{d}}$ & $21.83 \pm 2.52^{\mathrm{c}}$ & $29.03 \pm 2.45$ & $24.16 \pm 2.38^{\mathrm{b}, \mathrm{c}}$ \\
\hline VFA, mmol.day ${ }^{-1}$ & $46.84 \pm 1.39$ & $39.32 \pm 2.02^{\mathrm{a}}$ & $44.83 \pm 1.49$ & $43.91 \pm 1.07$ \\
\hline Acetate & $26.76 \pm 0.66^{\mathrm{b}}$ & $18.27 \pm 0.91$ & $23.84 \pm 0.78^{b}$ & $24.73 \pm 0.64^{\mathrm{b}}$ \\
\hline Propionate & $8.91 \pm 0.44^{\mathrm{c}}$ & $9.57 \pm 0.73^{c}$ & $11.6 \pm 0.29^{d}$ & $9.08 \pm 0.39$ \\
\hline n-butyrate & $7.02 \pm 0.28^{c}$ & $5.99 \pm 0.34$ & $5.32 \pm 0.44$ & $6.28 \pm 0.23$ \\
\hline $\mathrm{A} / \mathrm{P}$ ratio & $3.02 \pm 0.07^{\mathrm{b}, \mathrm{c}, \mathrm{d}}$ & $1.93 \pm 0.07^{\mathrm{d}}$ & $1.93 \pm 0.07$ & $2.73 \pm 0.06^{\mathrm{c}}$ \\
\hline Acetate,mol\% & $57.50 \pm 0.40^{\mathrm{b}, \mathrm{c}, \mathrm{d}}$ & $46.48 \pm 0.22^{\mathrm{c}, \mathrm{d}}$ & $53.18 \pm 0.11^{\mathrm{d}}$ & $56.31 \pm 0.12$ \\
\hline Propionate, $\mathrm{mol} \%$ & $19.07 \pm 0.39^{\mathrm{b}, \mathrm{c}}$ & $24.23 \pm 0.88^{\mathrm{d}}$ & $25.95 \pm 0.53$ & $20.65 \pm 0.46^{\mathrm{c}}$ \\
\hline n-butyrate,mol\% & $15.0 \pm 0.25^{\mathrm{c}}$ & $15.24 \pm 0.38$ & $11.79 \pm 0.68^{\mathrm{b}}$ & $14.32 \pm 0.50^{\mathrm{c}}$ \\
\hline $\mathrm{E}, \%$ & $75.05 \pm 0.42^{\mathrm{b}, \mathrm{c}}$ & $78.21 \pm 0.56^{\mathrm{d}}$ & $77.70 \pm 0.35$ & $75.68 \pm 0.52^{\mathrm{c}}$ \\
\hline OMF, g.day ${ }^{-1}$ & $4.57 \pm 0.21$ & $4.03 \pm 0.21$ & $4.30 \pm 0.18$ & $4.29 \pm 0.22$ \\
\hline $\mathrm{N}_{\mathrm{M}}$, mg.day $^{-1}$ & $124.37 \pm 4.05^{\mathrm{b}, \mathrm{c}, \mathrm{d}}$ & $88.13 \pm 3.92^{\mathrm{c}}$ & $65.14 \pm 3.85^{\mathrm{d}}$ & $86.81 \pm 4.22$ \\
\hline EMS, mg.g ${ }^{-1}$ & $27.33 \pm 1.12^{\mathrm{b}, \mathrm{c}, \mathrm{d}}$ & $22.21 \pm 1.25^{\mathrm{c}}$ & $15.26 \pm 1.38^{\mathrm{d}}$ & $20.28 \pm 1.27$ \\
\hline
\end{tabular}

LO+RO -mixture of linseed and rapeseed oil; FO+LO - mixture of fish and linseed oil; FO+LO+RO - mixture of all three oils; DMD - dry matter digestibility; NDF - neutral detergent fibre; ADF - acid detergent fibre; $\mathrm{E}$ - energetic efficiency of volatile fatty acids; OMF - organic matter fermented; $\mathrm{N}_{\mathrm{M}}$ - nitrogen incorporated by microflora; EMS - efficiency of microbial protein synthesis; \pm SEM (standard error of mean); values in a row with different superscripts ( ${ }^{\mathrm{a}, \mathrm{b}, \mathrm{c}, \mathrm{d}}$ ) differ at $\mathrm{P}<0.05$ 
increased propionate production $\left(\mathrm{mmol}^{-} \mathrm{day}^{-1}\right)$. The molar proportions of propionate were significantly increased with $\mathrm{LO}+\mathrm{RO}$ (about 5.2\%) and $\mathrm{FO}+\mathrm{LO}$ (about 6.9\%) in comparison with the control diet. The LO+FO blend also caused a decrease in n-butyrate production and its molar proportion in the diet. The calculation data for acetate to propionate production showed a significant $(\mathrm{P}<0.005)$ decrease of the $\mathrm{A} / \mathrm{P}$ ratio in the experimental diets. The energetic efficiency of VFA (E,\%) significantly increased, mainly with LO+FO and LO+RO. Several reports have indicated both a beneficial effect of PUFA on microbial protein synthesis (Broudiscou et al., 1994) as well as a negative one (Czerkawski et al., 1975). According to our results, all of the oil blends supplemented to the high forage diet significantly decreased EMS $(\%)$.

\section{CONCLUSIONS}

It can be stated that the oil blends $(\mathrm{LO}+\mathrm{RO}, \mathrm{LO}+\mathrm{RO}, \mathrm{LO}+\mathrm{RO}+\mathrm{FO})$ added at $5 \%$ in $\mathrm{DM}$ to the high forage diet did not affect rumen fermentation parameters $(\mathrm{pH}$, dry matter, total VFA production); the same oil blends significantly reduced the $\mathrm{mol} \%$ of acetate $(\mathrm{LO}+\mathrm{RO}, \mathrm{LO}+\mathrm{FO})$, n-butyrate $(\mathrm{LO}+\mathrm{FO}), \mathrm{A} / \mathrm{P}$ ratio (all oil blends), and increased the mol $\%$ of propionate $(\mathrm{LO}+\mathrm{RO}, \mathrm{LO}+\mathrm{FO})$. Finally, all of the oil blends significantly decreased the efficiency of microbial protein synthesis in the experimental diets.

\section{REFERENCES}

Abu Ghazaleh A.A., Schingoethe D.J., Hippen A.R., Kalscheur K.F., 2004. Conjugated linoleic acid increases in milk when cows are fed fish meal and extruded soybeans for an extended period of time. J. Dairy Sci. 87, 1758-1766

Broudiscou L., Pochet S., Poncet C., 1994. Effect of linseed oil supplementation on feed degradation and microbial synthesis in rumen ciliate-free and refaunated sheep. Anim. Feed Sci. Tech. 49, 189-202

Czerkawski J.W., Christie W.W., Breckenridge G., Hunter M.L., 1975. Changes in the rumen metabolism of sheep given increasing amounts of linseed oil in their diet. Brit. J. Nutr. 34, 25-44

Jalč D., Čertík M., 2005. Effect of microbial oil, monensin and fumarate on rumen fermentation in artificial rumen. Czech J. Anim. Sci. 50, 467-472

Jalč D., Potkański A., Szumacher-Strabel M., Kowalczyk J., Cieślak A., 2006a. The effect of a forage diet and different fat sources on rumen fermentation in vitro. J. Anim. Feed Sci. 15, Suppl. 1, 129-134

Wachira A.M., Sinclair L.A., Wilkinson R.K., Hallett K., Enser M., Wood J.D., 2000. Rumen biohydrogenation of $n-3$ polyunsaturated fatty acids and their effects on microbial efficiency and nutrient digestibility in sheep. J. Agr. Sci. 135, 419-428 